\title{
Histochemical characterization of glycoproteins in the gills of the carp (Cyprinus carpio)
}

\author{
Kenan ÇINAR, Nurgül ŞENOL, M. Rüştü ÖZEN \\ Department of Biology, Faculty of Arts and Sciences, Süleyman Demirel University, Isparta, Turkey.
}

\begin{abstract}
Summary: The characteristics of the mucous cells located in gills of the fish Cyprinus carpio were investigated. Mucous cells were determined from gill arc, gill body, primary and secondary lamellae. Mostly mucous cells had oval-globular shape throughout all regions. Histochemical analysis of the gill of Cyprinus carpio showed that mucous content included glycogene and/or oxidizable dioles $(\mathrm{PAS}+)$, neutral or acid-rich $(\mathrm{PAS} / \mathrm{AB} \mathrm{pH} 2.5+)$, sialic acid residues $(\mathrm{KOH} / \mathrm{PAS}+)$ and strong acid sulphated $(\mathrm{AF}+)$ glycoproteins (GPs). Except these mucosubstances, carboxyl groups and/or with sulphate esters $(\mathrm{AB} p H 2.5+)$ strong sulphate $(\mathrm{AB}$ $\mathrm{pH} 0.5+)(\mathrm{AF} / \mathrm{AB} \mathrm{pH} 2.5+)$, O-sulphate esters ( $\mathrm{AB}$ pH 1+) glycoproteins were also determined.
\end{abstract}

Key words: Cyprinus carpio, density, gill, glycoproteins, mucous cells

\section{Sazan (Cyprinus carpio) solungaç glikoproteinlerinin histokimyasal özellikleri}

Özet: Cyprinus carpio solungaçlarında yer alan karakteristik mukus hücreleri incelendi. Mukus hücreleri solungaç arklarında, solungaç lamellerinde, primer ve sekonder lamellerde tespit edildi. Tüm bölgeler boyunca mukus hücrelerinin çoğu oval-yuvarlak bir şekle sahipti. Histokimyasal analizler solungaçlardaki mukus hücrelerinin glikojen ya da oksidizable diolleri (PAS + ), nötral ya da asitce zengin (PAS/AB pH 2.5+), siyalik asid rezidulleri $(\mathrm{KOH} / \mathrm{PAS}+$ ) ve asitce zengin sulfatlı $(\mathrm{AF}+)$ glikoproteinleri içerdiği gösterildi. Bu mukosubstanslar dişında karboksil gruplu ya da sülfat esterli $(\mathrm{AB} p H 2.5+)$ güçlü sülfatlı $(\mathrm{AB} p H 0.5+)(\mathrm{AF} / \mathrm{AB} \mathrm{pH}$ $2.5+$ ), O-sülfat esterli (AB pH 1+) glikoproteinler tespit edildi.

Anahtar sözcükler: Cyprinus carpio, glikoproteinler, mukus hücreleri, solungaç, yoğunluk.

\section{Introduction}

The fish gill epithelium consists of several cell types. Many studies of fish gills have described the morphological and functional characteristics of gill epithelial cells: respiratory cells, chloride or mitochondria-rich cells, pavement cells and mucous cells $(4,9,19,22)$. As well as some studies is reported the branchial lamellae epithelium consists of granular cells, ciliated cells, leydig cells, bazal cells (17), undifferentiated cells (4), and accessory cells (1). Mucus producing cells integrate a variety of critical functions. Physiologically, mucus is important for protection and inhibition of micro-organisms $(5,27,36)$. This function is occurred by mucous glycoproteins (GPs) $(5,15,24$, 35 ), as well as the GPs are identified with O-sulphate esters are responsible for the lubrication (8). In addition, mucus membran is engaged important functions, such as osmoregulation, diffusion and protection of dehydration $(8,19,24,36)$.

Mucus producing cells are numerically and morphologically affected by different conditions as other cells localized in gill epithelium. Increase of mucous cells number is reported with different conditions such as bacterial gill disease (12), amoebic gill disease (26, 30,
$33)$, high concentrations of ammonia $(12,16)$, salinity $(2$, $13)$, acidity $(6,20)$, high pressure and low temparature (10). On the other hand, in conditions of high concentrations of ammonia (16), low $\mathrm{pH}$ (37), high concentrations of aluminum (29), heavy metals (18), substrat of diazinon (11) and acid plus aluminum (6), mucous cells size is increased. It is claimed that, numerically and morphologically the difference in mucous cells probably relates to period of secretion. In this study, our aim was to determine the mucous cells of the gills of the Carp (Cyprinus carpio) with histochemical technique

\section{Materials and Methods}

In this study we choosed the omnivorous fish species, Cyprinus carpio. We obtained these fish at Eğirdir lake. As material, twenty five uninfected Cyprinus carpio, length between $25-30 \mathrm{~cm}$ and weight between $320-350 \mathrm{~g}$, were used. Water conditions were showed in table 1 . The gills were rapidly excised and fixed by immersion in 10\% buffered formalin for light microscopic studies. The samples were routinely processed and embedded in parafin. Histochemical techniques were performed for the density and differentiation of carbohydrate moieties (Table 2). 
Table 1. Water conditions (Photometer method, soil pool) Tablo 1. Su değerleri (Fotometre yöntemi, toprak havuzu)

\begin{tabular}{lcc}
\hline Water conditions & Abbreviations & Water assets \\
\hline Potassium & $(\mathrm{K})$ & $2.7 \mathrm{mg} / 1$. \\
Sulphate & $\left(\mathrm{SO}_{4}\right)$ & $5 \mathrm{mg} / \mathrm{l}$. \\
Phosphate & $\left(\mathrm{PO}_{4}\right)$ & $5 \mathrm{mg} / 1$. \\
Chlorine & $(\mathrm{Cl})$ & $4 \mathrm{mg} / 1$. \\
Ammonium & $\left(\mathrm{NH}_{4}\right)$ & $0.06 \mathrm{mg} / 1$. \\
Nitrate (nitrogen of nitrat) & $\left(\mathrm{NO}_{3}\right)$ & $0.6 \mathrm{mg} / 1$. \\
Nitrate (total nitrat) & $\left(\mathrm{NO}_{3}\right)$ & $3.6 \mathrm{mg} / 1$. \\
Alkalinity & $\left(\mathrm{CaCO}_{3}\right)$ & $300 \mathrm{mg} / 1$. \\
Salinity & & $\% 3$ \\
pH & & 7.5 \\
Conductor & & $522 \mu \mathrm{s}$ \\
\hline
\end{tabular}

Table 2. Performed the histochemical techniques in the gill epithelium of Cyprinus carpio; $\mathrm{AB}$, Alcian blue; $\mathrm{KOH}$, saponification; PAS, periodic acid/Schiff; AF, Aldehyde fuchsin; GPs, glycoproteins.

Tablo 2. Cyprinus carpio solungaç epitelinde uygulanan histokimyasal teknikler; $\mathrm{AB}$, Alsiyan mavisi; $\mathrm{KOH}$, saponifikasyon; PAS, periyodik asit/Shif; AF, Aldehit fuksin; GPs, glikoproteinler.

\begin{tabular}{ll}
\hline Procedures & References \\
\hline 1. PAS & Mc Manus \\
GPs with oxidizable vicinal diols and/or & $(1948)$ \\
glycogen & \\
2. PAS/AB pH 2.5 & Mowry (1956) \\
Neutral and/or acid rich GPs & \\
3. AB pH 2.5 & Lev and Spicer \\
GPs with carboxyl groups (sialic acid or & $(1964)$ \\
uranic acid) and/or with sulphate esters & \\
4. AB pH 1.0 & Lev and Spicer \\
GPs with O-sulphate esters & $(1964)$ \\
5. AB pH 0.5 & Lev and Spicer \\
Very sulphated GPs & $(1964)$ \\
8. KOH/PAS & Culling et al. \\
GPs with sialic acid residues & $(1976)$ \\
9. AF & Gomari (1952) \\
GPs with sulphate & \\
10. AF/AB pH 2.5 & Spicer and Meyer \\
Strong sulphated GPs & $(1960)$ \\
\hline
\end{tabular}

\section{Results}

As a result of histochemical studies, mucous cells were determined from gill arc, gill body, primary and secondary lamellae. Density in gill arc and body was higher. Respectively primary and secondary lamellae followed these (Table 3). At the bases of secondary lamellae, such cells were detected as single cells or sometimes in groups. Mucous cells were observed to occur towards the outer surface, but sometimes in deeper layers. Mostly mucous cells had oval-globular shape throughout in all regions. Exceptionally some were in goblet shape, rather commonly in the gill arc. Despite foamy or cloudy appearance at mucous cell cytoplasms, seldomly cells had granular cytoplasms.
Table 3. Histochemical reactions of glycoproteins in the gills of Cyprinus carpio; $\mathrm{AB}$, Alcian blue; $\mathrm{KOH}$, saponification; $\mathrm{PAS}$, periodic acid/Schiff; AF, Aldehyde fuchsin; GPs, glycoproteins. Tablo 3. Cyprinus carpio solungaç epitelinde histokimyasal reaksiyonlar; $\mathrm{AB}$, Alsiyan mavisi; $\mathrm{KOH}$, saponifikasyon; PAS, periyodik asit/Shif; AF, Aldehit fuksin; GPs, glikoproteinler.

\begin{tabular}{lcccc}
\hline Procedures & \multicolumn{4}{c}{ Staining reactions } \\
\cline { 2 - 5 } & Gill arc & Gill body & $\begin{array}{c}\text { Primer } \\
\text { lamellae }\end{array}$ & $\begin{array}{c}\text { Sekonder } \\
\text { lamellae }\end{array}$ \\
\hline PAS & +++ & ++ & ++ & + \\
PAS/AB pH 2.5 & +++ & ++ & ++ & + \\
AB pH 2.5 & ++ & +++ & ++ & + \\
AB pH 1.0 & ++ & +++ & ++ & + \\
AB pH 0.5 & ++ & +++ & ++ & + \\
KOH/PAS & +++ & ++ & ++ & + \\
AF & ++ & +++ & ++ & + \\
AF/AB pH 2.5 & ++ & +++ & ++ & + \\
\hline & & & &
\end{tabular}

Alcian blue (AB) $\mathrm{pH} 1$ (Figure 1), $\mathrm{AB}$ pH 2.5 (Figure 2), periodic acid/schiff (PAS) and aldehyde fuchsin (AF) applications were intense in all regions, while $\mathrm{AB}$ pH 0.5 (Figure 4,5 ) was somewhat weaker. $\mathrm{AB}(+)$, PAS $(+)$ and $\mathrm{AF}(+)$ mucosubstances were dominant in $\mathrm{PAS} / \mathrm{AB} \mathrm{pH} 2.5$ (Figure 3), saponification / periodic acid/schiff (KOH/PAS), AF/AB applications respectively. In gill arc of some cells only $\mathrm{AB}(+)$ mucosubstances were observed in $\mathrm{PAS} / \mathrm{AB} \mathrm{pH}$ 2.5. similar results were obtained in $\mathrm{AF} / \mathrm{AB}$ application. But in $\mathrm{AF} / \mathrm{AB}$ application, cells away from lumen surface also showed $\mathrm{AF}(+)$ reaction at secondary lamella.

\section{Discussion and Conclusion}

Studies with different fish species shows that gill mucous cells distributed in different areas and different densities. In Poecilia vivipara (31) these were observed in apical of gill filaments only in interlamellar region and gill arc. In Micropogonias furnieri (9), mucous cells were observed in primary and secondary lamellae, while in Acipenser naccarii (4) along the filaments, rarely between pavement cells. In this study, mucous cells were identified to be broadly distributed in gills, rather in gill arc. Mucous cells were mostly in oval-globular in shape less commonly in goblet or pear-shaped, similar to Morone saxatilis or M. chrysops (28).

In accordance with Diaz et al (8), except for primary and secondary lamellae, mucous cell glycoprotein characterization was almost the same. Also in PAS/AB pH 2.5 applications similar results were obtained $(1,3)$. The AB dominance also has been obtained in Solea senegalensis (1), as in Cyprinus carpio in this study.

In $\mathrm{AB}$ pH 2.5 applications glycoprotein with carboxyl groups are more common, while freshwater adapter Salmo species (33) they are found less 


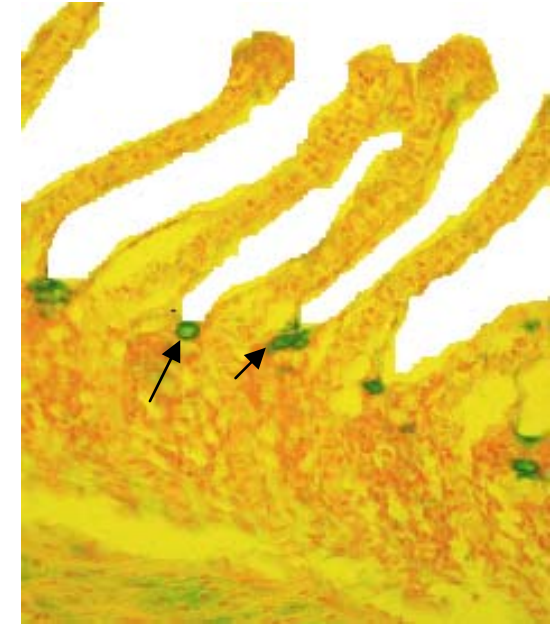

Figure 1. Secondary lamella, GPs with Osulphate esters in mucous cells. $\mathrm{AB} \mathrm{pH}$ 1.0. X 200

Şekil 1. Sekonder lamel, O-sülfat esterli glikoprotein içeren mukus hücreleri $\mathrm{AB}$ pH 1.0. X 200

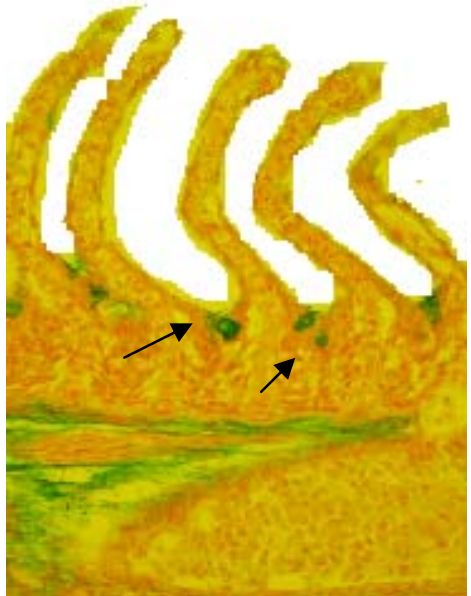

Figure 2. Secondary lamella, GPs with carboxyl groups (sialic acid and/or with sulphate esters in mucous cells. $\mathrm{AB} \mathrm{pH}$ 2.5. X 200

Şekil 2. Sekonder lamel, karboksil gruplu sülfat esterli glikoprotein içeren mukus hücreleri $\mathrm{AB} \mathrm{pH}$ 2.5. X 200

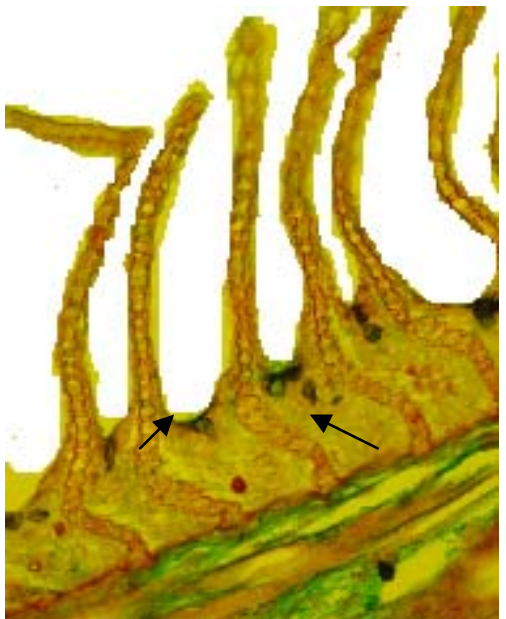

Figure 3. Secondary lamella, GPs with carboxyl groups and/or with sulphate esters in mucous cells $\mathrm{PAS} / \mathrm{AB}$ PH 2.5 (AB dominant) X 200

Şekil 3. Sekonder lamel, karboksil gruplu sülfat esterli glikoprotein içeren mukus hücreleri PAS/AB pH 2.5 X 200

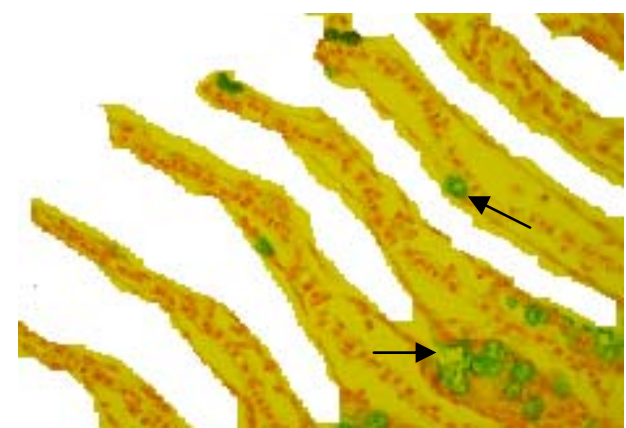

Figure 4. Secondary lamella, very sulphated GPs in mucous cells AB pH 0.5 X 200

Şekil 4. Sekonder lamel, güçlü sülfatlı glikoprotein içeren mukus hücreleri $\mathrm{AB}$ pH 0.5 X 200

frequently. Similar is case for Solea senegalensis (1), differing in that there were also some cells equally comprising $\mathrm{AB}$ pH 2.5 and PAS (+) mucosubstances.

Similar to study, in Acipenser naccarii (8) acclimated to sea, great portion of mucous cells are observed to react with PAS (+). Also similar to $M$. furnieri (8), sialic acid residues, glycoproteins with oxidizable vicinal diols are observed. Similar to Solea senegalensis (32) adults, in Cyprinus carpio strong sulphated GPs were encountered with $\mathrm{AB} \mathrm{pH} 0.5$ and $\mathrm{AF} / \mathrm{AB}$ applications. Likewise glycoprotein with sulphate groups seen in M. furnieri (8) and Salmo salar (33) acclimated to sea water were also observed in Cyprinus carpio in this study.

\section{References}

1. Arellano JM, Storch V, Sarasquete C (2004): Ultrastructural and histochemical study on gills and skin of the Senegal sole, Solea senegalensis. J Appl Ichthyol, 20, $452-460$.

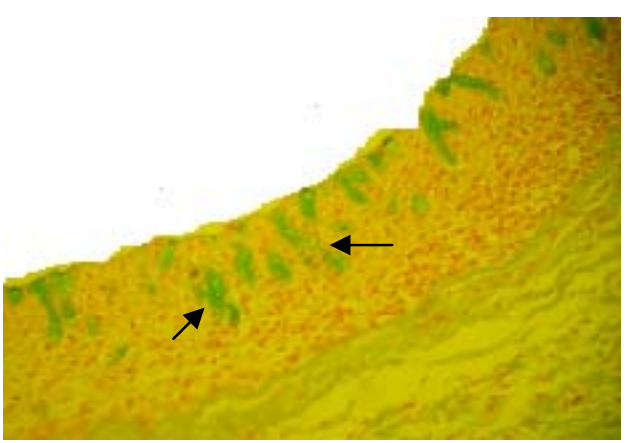

Figure 5. Gill arc, very sulphated GPs in mucous cells AB pH 0.5 X 200

Şekil 5. Solungaç yayı, güçlü sülfatlı glikoprotein içeren mukus hücreleri $\mathrm{AB}$ pH 0.5 X 200

2. Bordas MA, Balebona MC, Chabrillon M, RodriguezMaroto JM, Morinigo MA (2003): Influence of temperature and salinity on the adhesion to mucous surfaces of gilt-head seabream (Sparus aurata L.) of pathogenic strains of Vibrio alginolyticus and Listonella anguillarum. B Eur Assoc Fish Pat, 23, 273-280.

3. Calabro C, Albanese MP, Lauriano ER, Martella S, Licata A (2005): Morphological, histochemical and immunohistochemical study of the gill epithelium in the abyssal teleost fish Coelorhynchus . Folia Histochem Cytobiol, 43, 51-56.

4. Carmona R, Garcia-Gallego M, Sanz A, Domezain A and Ostos-Garrido MV (2004): Chloride cells and pavement cells in gill epithelia of Acipenser naccarii: ultrastructural modifications in seawater-acclimated specimens. J Fish Biol, 64, 553-566.

5. Chabrillon M, Bordas MA, Morimigo MA, Balebona MC (2004): Kinetics of adhesion of Listonella anguillarum to the mucus of gilt-head sea bream, and the implication of surface components. Aquac Res, 35, 403-409.

6. Charles HJ, Terry AH (1997): Changes in gill morphology of atlantic salmon (Salmo salar) smolts due to 
addition of acid and aluminium to stream water. Environ Pollut, 97, 137-146.

7. Culling CFA, Reid PE, Dunn WL (1976): A new histochemical method for the identification and visualization of both side chain acylated and non-acylated sialic acids. J Histochem Cytochem, 24, 1225-1230.

8. Diaz AO, Garcia AM, Devincenti CV, Goldemberg AL (2001): Mucous cells in Micropogonias furnieri gills: histochemistry and ultrastructure. Anat Histol Embryol, 30, 135-139.

9. Diaz AO, Garcia AM, Devincenti CV, Goldemberg AL (2005): Ultrastructure and histochemical study of glycoconjugates in the gills of the White Croaker (Micropogonias furnieri). Anat Histol Embriyol, 34, 117-122.

10. Dunel EB, Sebest P, Chevalier C, Simon B, Bart HL (1996): Morphological changes indiced by acclimation high pressure in the gill epithelium of the freshwater Yellow Eel. J Fish Biol, 48, 1018-1022.

11. Dutar HM, Richmands CR, Zeno T (1993): Effect of diazinon on the gills of Bluegill Sunfish, Lepomis macrochirus J Environ Pathol Toxicol Oncol, 12, 219-227.

12. Ferguson HW, Morrison D, Ostland VE, Lumsden J, Byme P (1992) : Response of mucus-producing cell in gill disease of Rainbow trout (Oncorhynchus mykiss). J Comp Pathol, 106, 255-265.

13. Franklin GC (1990): Surface ultrastructural changes in the gills of Sockeye salmon (Teleostei: Oncorhynhus nerka) during seawater transfer: comparison of successful seawater adoptation. J Morphol, 206, 13-23.

14. Gomari G (1952): Gomari's aldehyde fuchsin stain. 238. In: Cellular Pathology Technique, CFA Culling, RT Allison, WT Barr (eds). Butterworths, London.

15. Herrler G, Rott R, Klenk HD, Muller HP, Shukla AK and Schauer R (1985): The receptor destroying enzyme of influenza $C$ virus is neuraminate- $O$ - acetyl esterase. Embo J, 4, 1503-1506.

16. Hilary M, Lease-Hansen-James A, Bergman-Harold L, Meyer-Joseph S (2003): Structural changes in gills of Lost River suckers exposed to elevated $\mathrm{pH}$ and ammonia concentrations. Comparative Biochemistry and Physiology Part C: Toxicol Pharmacol, 134, 491-500.

17. Jarial MS, Wilkins JH (2003): Ultrastructure of the external gill epithelium of the axolotl, Ambystoma mexicanum with reference to ionic transport. J Submicrosc Cytol Pathol, 35,445-455.

18. Jezierska B, Witeska M (2004): The effect of metals on fish gill functions-Gas and ion change (review). Fresenius Environ Bullet, 13, 1370-1378.

19. Laurent P, Perry SF (1990): Effect of cortisol on gill chloride cell morphology and ionic uptake in the freshwater trout, Salmo gairdneri. Cell Tissue Res, 259, 429-442.

20. Ledy K, Giamberini L, Pihan PC (2003): Mucous cell responces in gill and skin of brown trout Salmo trutta fario in acidic, aluminium containing stream water. Dis Aquat Organ, 56, 235-240.

21. Lev R, Spicer SS (1964): Specific staining of sulphate groups with alcian blue at low pH. J Histochem Cytochem, 12, 309.

22. Matei VE (1993): Changes in the cellular ultrastructure of the gill epithelium in Tilapia under the action of cadmium on the fish. Tsitol, 35, 34-41.

23. McManus JFA (1948): Histological and histochemical uses of periodic acid. Stain Technol, 23, 99-108.
24. Mittal AK, Fujimori O, Ueda T, Yamada K (1995): Carbohydrates in the epidermal mucous cells of a freshwater fish Mastacembelus (Mastacembelidae, Pisces) as studied by electron-microscopic cytochemical methods. Cell Tissue Res, 280, 531-539.

25. Mowry RW (1956): Alcian blue techniques for the histochemical study of acidic carbohydrates. J Histochem Cytochem, 4, 407-408.

26. Munday BL, Zilberg D, Findlay V (2001): Gill disease of morine fish caused by infection with Neoporamoeba pemaguidensis. J Fish Dis, 24, 497-507.

27. Park CM, Reid PE, Owen DA, Volz D, Dunn WL (1987): Histochemical studies of epithelial cell glycoproteins in normal rat colon. Histochem J, 19, 546-554.

28. Pfeiffer CJ, Smith BJ, Smith SA (1999): Ultrastructural morphology of the gill of the hybrid striped bass (Morone saxatilis X M. chrysops). Anat Histol Embryol 28, 337344.

29. Playle RC, Wood CM (1991): Mechanisms of aluminium extraction and accumilation at the gills of rainbow trout, Oncorhynchus mykiss (Walbaum), in acidic soft water. J Fish Biol, 38, 791-805.

30. Powell MD, Porsons HJ, Nowak BF (2001): Physiological effects of freshwater bathing of Atlantic salmon (Salmo salar) as a treatment for amoebic gill disease. Aquaculture,199,259-266.

31. Sabaoia-Moraes SMT, Hernandez-Blazquez FJ, Mota DL, Bittencourt AM (1996): Mucous cell rypes in branchial epithelium of the euryhaline fish Poecilia vivipara. J Fish Biol, 49, 549-558.

32. Sarasquete C, Canales MLG, Arellano J, Cueto JAM, Ribeiro L, Dinis MT (1998): Histochemical study of skin and gills of Senegal solea, Solea senegalensis larvae and adults. Histol Histopathol, 13, 727-735.

33. Shane DR, Powell MD (2003): Comparative ionic flux and gill mucous cell histochemistry: effects of salinitiy and disease status in Atlantic salmon (Salmo salar L.). Comp Biochem Physiol Part A: Molecular and Integrative Physiology, 134, 525-537.

34. Spicer SS, Meyer DB (1960): Aldehyde fuchsin / alcian blue. 233. In: Cellular Pathology Technique, CFA Culling, RT Allison, WT Barr (eds). Butterworths, London.

35. Suprasert A, Fujioka T, Yamada K (1987): The histochemistry of glycoconjugates in the colonic epithelium of the chicken. Histochemistry, 86, 491-497.

36. Whitear M (1986): The skin of fishes including cyslostomes epidermis. 8-38. In: Biology of the Integument, Vol. 2. Vertebrates, J Bereiter-Hahn, AG Matoltsy, KS Richards (eds). Springer-Verlag, Berlin.

37. Wilson RW, Bergman HL, Wood CM (1994): Metabolic costs and physiological consequences of acclimation to aluminium in juvenile rainbow trout, Oncorhynchus mykiss (Walbaum), gill morphology, swimming performance and aerobic scope. Can Fish Aquat Sci, 51, 536-544.

Gelis tarihi: 05.02.2007 / Kabul tarihi: 16.05.2007
Address for correspondance
Dr. Kenan Çinar
Department of Biology
Faculty of Arts and Sciences
Süleyman Demirel University
32260, Isparta, Turkey
e-mail:kcinar@fef.sdu.edu.tr 